ISA

Arboriculture \& Urban Forestry 2016. 42(5): 346-354

\title{
Potential of Alternative Tsuga spp. as Landscape Replacements for $T$. canadensis: Longer-Term Evaluation and Propagation of T. chinensis.
}

\author{
Richard W. Harper and Paul A. Weston
}

\begin{abstract}
Seven species of hemlock (Tsuga spp.) - four from North America and three from Asia-were evaluated in replicated plots in Katonah, New York, United States (USDA Plant Hardiness Zone 6b) as potential replacements for eastern hemlock (Tsuga canadensis), which is gradually being extirpated from landscapes in the eastern United States. by the invasive hemlock woolly adelgid (Adelges tsugae). Trends reported in an earlier study (Weston and Harper 2009) continued but were exaggerated after an additional three years of observation. For example, Chinese hemlock (T. chinensis) continued to show the greatest potential as a replacement for T. canadensis as mortality was very low, overall plant health was exceptional, and tolerance to A. tsugae was robust. Early indicators suggest that $T$. chinensis may also be readily propagated from hardwood cuttings under appropriate greenhouse conditions. These characteristics suggest that T. chinensis may indeed become a viable replacement for T. canadensis, and a valuable addition to landscapes in the eastern U.S.

Key Words. Elongate Hemlock Scale; Hemlock; Hemlock Woolly Adelgid; Host Resistance; Tsuga canadensis; Tsuga caroliniana; Tsuga chinensis; Tsuga diversifolia; Tsuga heterophylla; Tsuga mertensiana; Tsuga sieboldii.
\end{abstract}

The use of pest-resistant host plants has long been accepted as an important part of a comprehensive integrated pest management (IPM) program (Larsson 2002; Dreistadt 2004). Trees that show potential resistance to a pest of importance, however, must be able to tolerate the climatic conditions in their newly planted locations. An important landscape tree that has been the focus of research seeking to find resistant accessions is eastern hemlock [Tsuga canadensis (L.) Carrière]. While T. canadensis has been an important component of managed and natural landscapes in the northeastern United States because of its size and stately presence, not to mention its importance in moderating temperature and retaining soil and unique assemblages of organisms in native habitats (Black and Mack 1976; Lapin 1994; Quimby 1995), it is gradually being extirpated by a small, invasive, sap-feeding insect from Asia, the hemlock woolly adelgid [Adelges tsugae (Annand)] (HWA). Tsuga spp. of Asian origin might be expected to possess resistance to A. tsugae because of prolonged exposure to the pest, owing to their broader common geographic origin (Bryant et al. 1994); Chinese hemlock [T. chinensis (Franch) E. Pritz] has indeed been reported as being highly resistant to $A$. tsugae (Del Tredici and Kitajima 2004; Hoover et al. 2009; Montgomery et al. 2009; Weston and Harper 2009).

Studies have examined the survivability and adaptability of hemlock (Tsuga spp.) in different parts of the U.S. but the research has been limited to a few species (Bentz et al. 2002). Although growth response and survivorship of some species of Asian hemlock, such as $T$. chinensis, existing outside their indigenous territories have been published (Del Tredici and Kitajima 2004), formal data are limited regarding other Tsuga spp. Additionally, published information regarding other factors, including susceptibility of Tsuga spp., which are not native to the northeastern U.S. to pests of economic impor- 
tance, such as HWA (Montgomery et al. 2009; Weston and Harper 2009), elongate hemlock scale (Fiorinia externa Ferris) (EHS) (Hoover et al. 2009; Harper and Cowles 2013), and spruce spider mite (Oligonychus ununguis Jacobi) (SSM) (Del Tredici and Kitajima 2004), may be limited or unavailable. Furthermore, when a specimen of Tsuga spp. has demonstrated resistance to a pest of importance like HWA (Bentz et al. 2002; Havill and Montgomery 2008), resistance mechanisms, though perhaps suspected to be mechanical or chemical in nature (Oten et al. 2010), may not actually be known (Bentz et al. 2002). Propagation techniques for Tsuga spp., especially $T$. canadensis, have been published (Del Tredici 1985; Jetton 2008), but little research has focused on the propagation of $T$. chinensis.

This study sought to better understand the longer term survivability and growth performance of seven species of Tsuga originating from western North America and Asia in the northeastern U.S., nearly nine years after they were planted in research plots in Westchester County, New York, U.S. Researchers also aimed to document the ability of $T$. chinensis to be propagated from hardwood cuttings in the early stage of vegetative propagation.

\section{MATERIALS AND METHODS}

\section{Research Site}

Located in Katonah, New York, U.S. (USDA Hardiness Zone 6b), Lasdon Park and Arboretum is a 94 ha public park that hosts various horticulture research and teaching interests (Anonymous 2013). On 30 September 2003, three experimental plots were established within the deer-fenced portion of the property, designated Front Gate, Magnolia Garden, and Hemlock Hedge.

\section{Plant Material}

Tsuga selection consisted of the following seven species based on commercial availability: Tsuga canadensis (L.) Carrière (Canadian/ eastern hemlock)-Although a highly valued ornamental tree in the northeastern U.S., its range extends south to Georgia and Alabama and west to Minnesota. Hardy to USDA Zone 3, it is also found growing at its northern range that extends into the central-eastern portion of southern Canada. Its response to shearing and tolerance to shade have made it an ideal hedge species, however. Its graceful form and size-the national champion is $47.5 \mathrm{~m}$ in height-also make this tree valued as an individual specimen tree or grouped planting (Farrar 1995; Dirr 2011). As HWA has reduced the salability of $T$. canadensis and its numerous cultivars throughout significant portions of the infestation range, horticulture specialists have continued to answer questions from arborists and other horticulture professionals, as well as the general public, about suitable woody ornamentals that may supplant the landscape niche that this tree has successfully occupied. Specifically, this includes the natural screening benefits from a maintained $T$. canadensis hedge, serving to divide shaded suburban properties (J. Giordano, Cornell University Cooperative Extension, pers. comm.). Numerous published reports have affirmed host susceptibility to HWA (Table 1) and 28 of the original 36 research specimens have persisted at Lasdon Arboretum (Table 2).

Table 1. Summary of Tsuga susceptibility to hemlock woolly adelgid (Adelges tsugae). Ratings are: $\mathrm{S}=$ susceptible, $\mathrm{T}=$ tolerant, $\mathrm{R}=$ resistant, ? = questionable.

\begin{tabular}{|c|c|c|c|c|c|c|c|}
\hline \multirow[b]{2}{*}{ Author(s)/year } & \multicolumn{7}{|c|}{ Species $^{z}$} \\
\hline & can & car & het & mer & div & sie & chi \\
\hline McClure/1992 & $\mathrm{S}$ & $\mathrm{S}$ & $\mathrm{T}$ & $\mathrm{T}$ & $\mathrm{S}$ & $\mathrm{S}$ & --- \\
\hline del Tredici \& Kitajima/2004 & S & $\mathrm{S}$ & $?$ & --- & $\mathrm{R}$ & $?$ & $\mathrm{R}$ \\
\hline Montgomery \& Lagalante/2008 & S & S & $?$ & $\mathrm{R}$ & $\mathrm{R}$ & S & $\mathrm{R}$ \\
\hline Montgomery et al./2009 & S & $\mathrm{S}$ & --- & --- & --- & S & $\mathrm{R}$ \\
\hline Weston \& Harper/2009 & $\mathrm{S}$ & $\mathrm{S}$ & S & $\mathrm{R}$ & $\mathrm{R}$ & $\mathrm{R}$ & $\mathrm{R}$ \\
\hline Harper \& Weston (current study) & $\mathrm{S}$ & $\mathrm{S}$ & $\mathrm{S}$ & $\mathrm{R}$ & $\mathrm{S}$ & $\mathrm{R}$ & $\mathrm{R}$ \\
\hline
\end{tabular}

${ }^{\mathrm{z}}$ Species abbreviations are as follows: $\mathrm{can}=$ T. canadensis, car $=$ T. caroliniana, het $=$ T. heterophylla, mer $=$ T. mertensiana, chi $=$ T. chinensis, div $=$ T. diversifolia, sie $=$ T. sieboldii.

Note: Dashes (---) indicate species that were not evaluated in certain studies. 
Table 2. Survival of seven species of Tsuga evaluated in test plots at Lasdon Park Arboretum. The number of trees in each of the plots planted in $\mathbf{2 0 0 3}$ and remaining alive in $\mathbf{2 0 1 2}$ is shown, along with percent survivorship for each plot and averaged across plots.

\begin{tabular}{|c|c|c|c|c|c|}
\hline \multirow[t]{2}{*}{ Species } & \multirow[t]{2}{*}{ Year } & \multicolumn{3}{|l|}{ Plot $^{2}$} & \multirow[t]{2}{*}{ Average $^{y}$} \\
\hline & & 1 & 2 & 3 & \\
\hline \multirow[t]{3}{*}{ T. canadensis } & 2003 & 12 & 12 & 12 & \\
\hline & 2012 & 6 & 8 & 12 & \\
\hline & $\%$ survival & 50.0 & 66.7 & 100.0 & 72.2 \\
\hline \multirow[t]{3}{*}{ T. caroliniana } & 2003 & 6 & 6 & 6 & \\
\hline & 2012 & 0 & 1 & 0 & \\
\hline & $\%$ survival & 0.0 & 16.7 & 0.0 & $5.6^{\star *}$ \\
\hline \multirow[t]{3}{*}{ T. chinensis } & 2003 & 6 & 6 & 6 & \\
\hline & 2012 & 6 & 5 & 6 & \\
\hline & $\%$ survival & 100.0 & 83.3 & 100.0 & 94.4 \\
\hline \multirow{3}{*}{ T. diversifolia } & 2003 & 6 & 6 & 6 & \\
\hline & 2012 & 1 & 2 & 0 & \\
\hline & $\%$ survival & 16.7 & 33.3 & 0.0 & $16.7^{\star \star}$ \\
\hline \multirow[t]{3}{*}{ T. heterophylla } & 2003 & 4 & 4 & 3 & \\
\hline & 2012 & 3 & 1 & 0 & \\
\hline & $\%$ survival & 75.0 & 25.0 & 0.0 & $33.3^{*}$ \\
\hline \multirow[t]{3}{*}{ T. mertensiana } & 2003 & 6 & 6 & 6 & \\
\hline & 2012 & 1 & 1 & 0 & \\
\hline & $\%$ survival & 16.7 & 16.7 & 0.0 & $11.1^{\star *}$ \\
\hline \multirow[t]{3}{*}{ T. sieboldii } & 2003 & 6 & 6 & 6 & \\
\hline & 2012 & 0 & 1 & 0 & \\
\hline & $\%$ survival & 0.0 & 16.7 & 0.0 & $5.6^{\star *}$ \\
\hline
\end{tabular}

${ }^{\mathrm{z}}$ Plot numbers are as follows: 1 - Front Gate, 2 - Magnolia Garden, 3 - Hemlock Hedge.

${ }^{\mathrm{y}}$ Asterisks indicate significant mortality as determined by $\chi^{2}$ test; ${ }^{*}=$ significant at $P<0.05,{ }^{* *}=$ significant at $P<0.01$.

Tsuga caroliniana Engelm. (Carolina hemlock)-Although not common in the horticulture trade with no formally recognized subspecies, forms, or varieties, several references to the ornamental application and value of this tree have been made (Dirr 2011). Tsuga caroliniana can be found in a limited range that includes southern Virginia, North Carolina, South Carolina, and Georgia, in the U.S. Its limited growing range often includes elevations between $640 \mathrm{~m}$ and $1220 \mathrm{~m}$ (Anonymous 2008), which seems to have limited both its exploitation as a significant contributor to either the forest products or ornamental horticulture industries (Coladonato 1993). Though it has been noted successfully growing well outside its range of origin as far north as Amherst, Massachusetts, U.S. (RWH, pers. observation), concerns related to climatic challenges from more northerly sites do not appear to have yet been formally researched; this information would be important as only one of the 18 research specimens have persisted at Lasdon Arboretum (Table 2). Still, this tree is shade tolerant, may grow to a height of up to $21 \mathrm{~m}$ and may offer some degree of promise in the horticulture trade (Coladonato 1993; Dirr 2011), although its susceptibility to HWA and EHS may inevitably be limiting. Numerous manuscripts detail host susceptibility to HWA (Table 1).

Tsuga heterophylla (Raf.) Sarg. (western hemlock)-Reputed as an elegant giant, reaching heights in excess of $60 \mathrm{~m}$, western hemlock is known as a versatile tree that can be found growing throughout moist/humid coastal regions of the pacific northwest region of the U.S., as well as inland among the various mountain ranges into Canada and as far north as Alaska, U.S. (Packee 1990). Its graceful appearance and tolerance to shearing and shade have endeared $T$. heterophylla as a landscape planting typically within its host range, and a number of varieties (cultivars) are commercially available (Anonymous 2014). It is described as being hardy to USDA Zone 6, and only four of the original 11 research specimens have survived at Lasdon Arboretum (Table 2). Numerous manuscripts affirm host susceptibility to HWA (Table 1). 
Tsuga mertensiana (Bong.) Carrière (mountain hemlock) - A significantly smaller tree than its native western counterpart (max. ht. about $30 \mathrm{~m}$ ), T. mertensiana is rarely found growing in close association with $T$. heterophylla, as it typically occupies the less temperate, more elevated mountainous sites of the pacific northwest U.S., Canada, and Alaska (Means 1990). Several varieties of this tree are available commercially (Anonymous 2014), presumably for landscape purposes. Although it is described as being hardy to USDA Zone 5, and though numerous manuscripts describe host resistance to HWA (Table $1)$, only two of the original 18 research specimens have persisted at Lasdon Arboretum (Table 2).

Tsuga chinensis (Franch.) E. Pritz (Chinese hemlock)-Described as attaining heights in excess of $30 \mathrm{~m}$ in China (Dirr 2011), T. chinensis has been growing successfully in Jamaica Plain, Massachusetts, U.S. (USDA Zone 6b) since a specimen was established at the Arnold Arboretum in 1910 by E.H. Wilson (Havill and Montgomery 2008). Thirty-eight $T$. chinensis seedlings that had been planted in 1999 were inventoried 09 March 2004 , identifying no post-winter mortality despite exposure to a low temperature of $-22.5^{\circ} \mathrm{C}$, which occurred on 16 January 2004 (Del Tredici and Kitajima 2004). Dirr (2011) describes T. chinensis hardiness to Zone 5, and 17 of the 18 specimens at Lasdon Arboretum have persisted (Table 2).

Tsuga diversifolia (Maximowicz) Masters (northern Japanese hemlock)-Occurring in northern Japan at higher elevations, this tree, records indicate, has been in commercial cultivation and trade since 1861 (Anonymous 2014). Although only three of the original 18 research specimens still persist at Lasdon Arboretum (Table 2), Dirr (2011) describes survivorship of this tree as far north as the state of Maine, U.S. (Zone 4) and reports observing specimens at heights of over $12 \mathrm{~m}$ in Congreve Gardens, Ireland. Although many manuscripts report host resistance to HWA (Table 1), findings among all references are not entirely consistent.

Tsuga sieboldii Carrière (Japanese hemlock)-Found naturally growing in southern Japan at lower elevations, this tree, records indicate, has been in cultivation and trade, successfully, since 1914 (Havill and Montgomery
2008). One of the original 18 research specimens remains living at Lasdon Arboretum (Table 2).

Tsuga canadensis, T. chinensis, and T. heterophylla were sourced from Eby Nursery, Wilsonville, Oregon, U.S., and T. caroliniana, T. diversifolia, T. mertensiana, and T. sieboldii were obtained from Forestfarm Nursery, Williams, Oregon, U.S.

\section{Plot Design}

Trial plots were approximately $12 \mathrm{~m} \times 14 \mathrm{~m}$, each, including six rows of the research trees spaced at approximately $2 \mathrm{~m}$ intervals. Species were planted in each row in random order and were intended to include at least one of each of the aforementioned seven Tsuga species as well as a second representative of $T$. canadensis per row. Because seven specimens of T. heterophylla and one $T$. caroliniana perished before time of planting (30 September 2003), some rows were lacking a complete complement of trees (the remaining specimens of $T$. heterophylla were distributed as evenly as possible among plots, Table 2). Daylight penetration on the plots ranged from full to partial sun throughout the day (Front Gate and Magnolia Garden plots), to nearly full shade provided by deciduous trees (Hemlock Hedge plot). Plots had been mulched annually, commencing in autumn 2006, with $5-10 \mathrm{~cm}$ depth of whole-tree mulch (i.e., assorted wood chips) from a municipal composting facility for the purposes of weed management, moisture retention, and soil temperature regulation. Prior to annual mulching, the area between the trees was mowed as needed during the summer to reduce vegetative competition from grasses and weeds. Soil samples within the plots were submitted to the University of Massachusetts (UMass) Soil Diagnostic Laboratory on 31 May 2013. Soil compaction readings were also taken in each plot at 12 random locations with a soil penetrometer (soil compaction tester, DICKEYjohn ${ }^{\oplus}$, Auburn, Illinois, U.S.) on 29 May 2013.

Trees were assessed for performance and pest occurrence on 19 and 24 July 2012. The height of trees was measured to the nearest $0.03 \mathrm{~m}$ using a telescopic measuring rod (Jameson, LLC, Clover, South Carolina, U.S.), and overall health was assessed visually, where each tree was assigned a rating from 0 (dead) to 5 (lush, dark green needles). The pres- 
ence or absence of HWA and EHS was noted after inspecting several branches from each tree using a simple binary (presence/absence) classification.

\section{Propagation of T. chinensis}

Hardwood cuttings of the most recent year's growth were taken from $T$. chinensis growing in the research plots on 20 January 2014, and averaged $12.5-15 \mathrm{~cm}$ in length. Cuttings were kept in closed plastic bags, transported to the UMass College of Natural Sciences greenhouse, and potted on 22 January 2014 (Figure 1). The cut ends were dipped in a liquid rooting concentrate (Dip'N Grow, Inc., Clackamas, Oregon, U.S.) at a concentration of 5,000 ppm IBA and 2,500 ppm NAA before potting in sand:perlite (1:1) in standard 50plug, $25.4 \mathrm{~cm} \times 50.8 \mathrm{~cm}$ grow trays. Two growing conditions were compared: 1) under a polyethylene (poly) moisture tent with bottom heat $\left(21^{\circ} \mathrm{C}\right)$, and 2) on a mist bench with no bottom heat (air temperature $24^{\circ} \mathrm{C}$ ). Four flats of 50 cuttings each (200 cuttings total) were reared in the poly tent and six flats (300 cuttings total) were reared on the mist bench. Rooting could not be verified until cuttings remained for a "3-4 month" period under the aforementioned conditions (J. Alexander, Arnold Arboretum at Harvard University, pers. comm.). Establishment and vigor were assessed at various times over the following ten months. Vigor was assessed visually on a whole-tray basis using a $0-5$ visual rating system, where $0=100 \%$ mortality of grow tray specimens and $5=100 \%$ viability and lush, green needles, similar to the vigor rating used to assess tree health in the field.

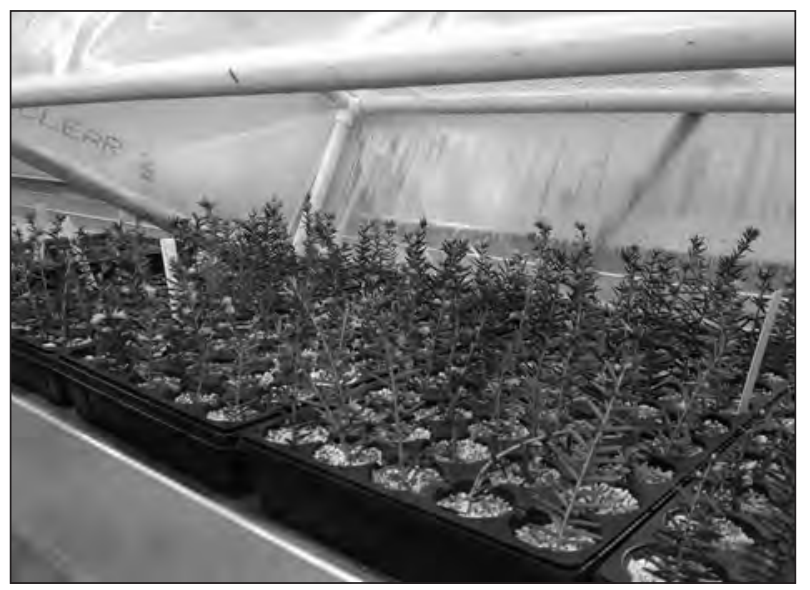

Figure 1. Early-stage Tsuga chinensis cuttings under poly tent in greenhouse.

\section{Data Analysis}

Tree height was analyzed using randomized complete block analysis of variance (ANOVA) and vigor was analyzed with Kruskal-Wallis one-way non-parametric ANOVA because the data did not meet the assumptions of randomized complete block ANOVA. Because of the low number of trees surviving for many of the test species, these analyses were performed only for T. canadensis and T. chinensis. Survivorship was analyzed for all species, using $\chi^{2}$ for the total number of each of the test species surviving, regardless of plot (replicate), and propagation results were analyzed with a two-sample t-test. Analyses were performed with Statistix 9 (Analytical Software, Tallahassee, Florida, U.S.).

\section{RESULTS AND DISCUSSION}

\section{Soil Analysis}

Texture-by-feel evaluation revealed a loam soil comprising the growing media in all three of the experimental plots in which the Tsuga spp. trees were growing. Bulk density readings were $0.96 \mathrm{~g} /$ cc (Front Gate), $0.98 \mathrm{~g} / \mathrm{cc}$ (Magnolia Garden), and $0.81 \mathrm{~g} / \mathrm{cc}$ (Hemlock Hedge). Bulk density may be one significant factor useful in identifying compacted soils; these values indicate that from a structural standpoint, the soil in the research plots was well below levels considered restrictive to root growth (i.e., $1.40-1.65 \mathrm{~g} / \mathrm{cc}$ ) (Alberty et al. 1984). This was further corroborated by data from the penetrometer readings, which revealed root penetration to a depth of $18-23 \mathrm{~cm}$ throughout the three plots: $19.2 \mathrm{~cm}$ (Front Gate), $17.9 \mathrm{~cm}$ (Magnolia Garden), and $21.3 \mathrm{~cm}$ (Hemlock Hedge). A significant layer of organic matter had accumulated on the three plots, which is likely responsible for the soil organic matter (SOM) reading of $10.4 \%$ in the Front Gate Plot, although SOM readings for the other two plots were more within normal levels of nearly 5\% (4.7\% Magnolia Garden; 3.8\% Hemlock Hedge) (Harris et al. 2004). The $\mathrm{pH}$ readings from the soil test report indicated the following values: Front Gate, 5.4; Magnolia Garden, 5.4; and Hemlock Hedge, 5.2. Since T. canadensis is found growing on soils that range from "very acidic" to "nearly neutral" (Godman and Lancaster 1990), these values should not be limiting factors. 
The pattern of tree growth observed between 2004 and 2008 (Weston and Harper 2009) largely continued between 2008 and 2012. Specimens of $T$. canadensis continued to measure the tallest of the seven species, but $T$. heterophylla was now similar in height to T. canadensis (Figure 2). Specimens of $T$. chinensis were nearly as tall as the tallest two species, but were significantly shorter than $T$. canadensis $(P<0.01)$, although the actual difference was relatively small. Specimens of $T$. diversifolia were numerically less than half as tall as the tallest trees, and the remaining species were minuscule in comparison (these differences were not statistically testable). Obtaining an accurate estimate of the height of the smallest was compromised because very few specimens of each of these species survived through 2012 (Table 2).

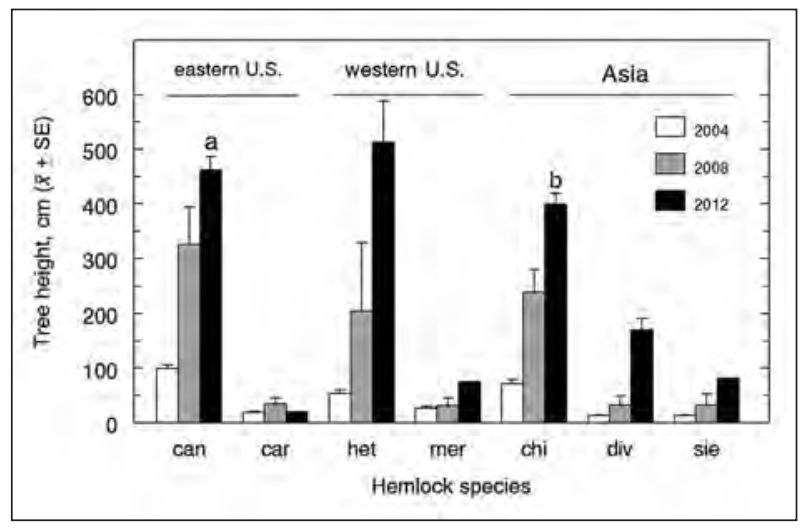

Figure 2. Height of Tsuga spp. in the research plots at Lasdon Park. Bars for 2012 accompanied by the same letter are not significantly different as determined by ANOVA followed by mean comparisons using LSD at $P=0.05$ (only $T$. canadensis and $T$. chinensis could be tested; see text for details). Species abbreviations are as follows: can $=T$. canadensis, car $=T$. caroliniana, het $=T$. heterophylla, mer $=T$. mertensiana, chi $=T$. chinensis, div $=T$. diversifolia, sie = T. sieboldii.

Substantial differences existed in the ability of the seven species to survive the conditions in the research plots in the northeastern U.S. The differences in survivorship among the species observed in 2008 (Weston and Harper 2009) were accentuated in 2012; the four species with the lowest survivorship in 2008 (T. caroliniana, T. mertensiana, T. diversifolia, and T. sieboldii) displayed even lower survivorship in 2012 (Table 2), ranging between $5 \%$ and $17 \%$. Tsuga canadensis and T. chinensis continued to display the highest survivorship, with values of $72.2 \%$ and $94.4 \%$, respectively. The biggest change from 2008 was T. heterophylla, which dropped from $75 \%$ to $36 \%$ survivorship, apparently suffering substantial winter mortality as evidenced by the consistent brown-chlorotic appearance of the foliage after each winter season. Specific information pertaining to the provenance of these Tsuga spp. was unavailable, and it is important to note that the particular area of origin of a species (and specimen) may influence factors like plant hardiness.

Another measure of performance of the test trees was the vigor rating. Vigor ratings for T. canadensis and T. chinensis were identical in 2008 at $4.2+0.4$ (mean + standard deviation), but dropped to $3.7+$ 0.8 for T. canadensis by 2012. On the other hand, the vigor rating of $T$. chinensis increased to $5.0+0.0$ in 2012. This difference in vigor rating was statistically significant $(F=60.0, \mathrm{df}=1,42, P<0.001)$.

\section{Pest Presence}

In 2008, populations of EHS were found on 73 and $35 \%$ of the specimens of T. canadensis and T. chinensis, respectively (Weston and Harper 2009). Data collection during July 2012 revealed HWA to be present on none of the 17 surviving specimens of T. chinensis, while EHS was present on all of the T. chinensis specimens (though no negative effects appeared to be associated with the presence of this insect on these trees). HWA was found to be present on 27 of the 28 surviving T. canadensis specimens (96.43\%), while EHS was found to be present on all T. canadensis trees in the study plots. In fact, all of the remaining specimens of Tsuga spp. were positively infested with EHS, regardless of species. These results would indicate that further study concerning this insect and its effect on various Tsuga spp. would be in order.

\section{Vegetative Propagation}

The $T$. chinensis cuttings that were potted as part of the exploratory propagation proof-of-concept were evaluated approximately six weeks after potting (28 February) and appeared to have started well; all of the 200 cuttings that were potted and placed under the poly tent with bottom heat had maintained their needles and were lush/green with buds flushing new growth. The cuttings under the mist heads also appeared to be getting a good start, with 296 of the 300 having maintained needles, a lush/green appearance, and new growth 
flushing from buds. The mean early-stage survival of the cuttings from the two methods was not significantly different $(t=-2.05, \mathrm{df}=8, P>$ $0.05)$. The early-stage survival rate observed for T. chinensis may be higher than that observed for hardwood cuttings of T. canadensis reported by Doran (1952) (65\%-71\%) and perhaps substantially higher than that reported for softwood cuttings of T. canadensis by Jetton et al. (2005) $(22 \%)$. A second assessment of transplant success and root establishment was conducted on 14 July 2014, approximately six months after transplant. Of the cuttings housed under the poly tent, 141 (70.5\%) demonstrated successful root formation; $186(62.0 \%)$ of the cuttings housed under mist heads demonstrated successful initial root formation. Biweekly evaluations taken between 14 July and 20 October 2014 revealed a steady decline in survivorship of cuttings under both cultivation methods; survivorship of cuttings under the poly tent had declined to $56.5+12.5 \%$ at the end of this period compared to $40.3+12.0 \%$ for cuttings under the mist heads. Although this difference was not statistically different, it sug- gests that cultivation under the poly tent will result in greater transplant establishment, which is supported by the higher visual rating for these cuttings $(3.8+0.5)$ compared with $3.1+0.6$ for cuttings held under the mist heads. This differential vigor of cuttings under the two cultivation methods is likely explained by the warmer, slightly drier rooting conditions associated with the heating pad and generally drier foliage in the poly tent (J. Kinchla, Amherst Nurseries, pers. comm.). Further evalu-

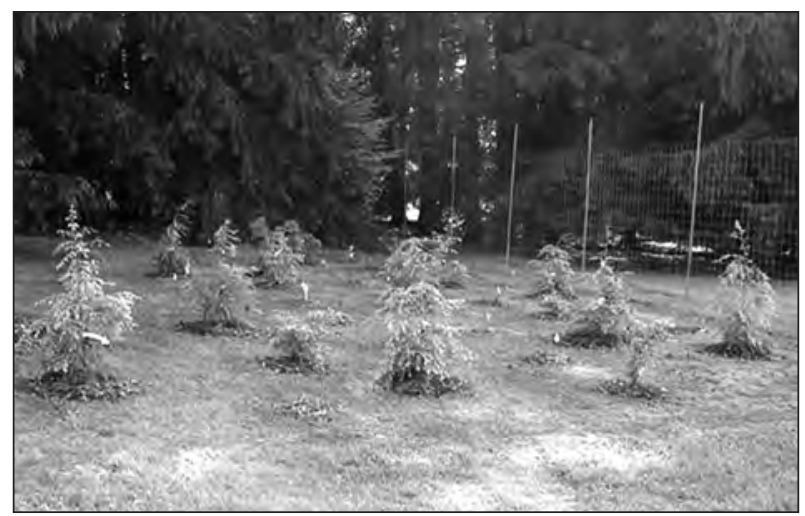

Figure 3. Tsuga spp. Front Gate plot at Lasdon Park \& Arboretum, spring 2004.

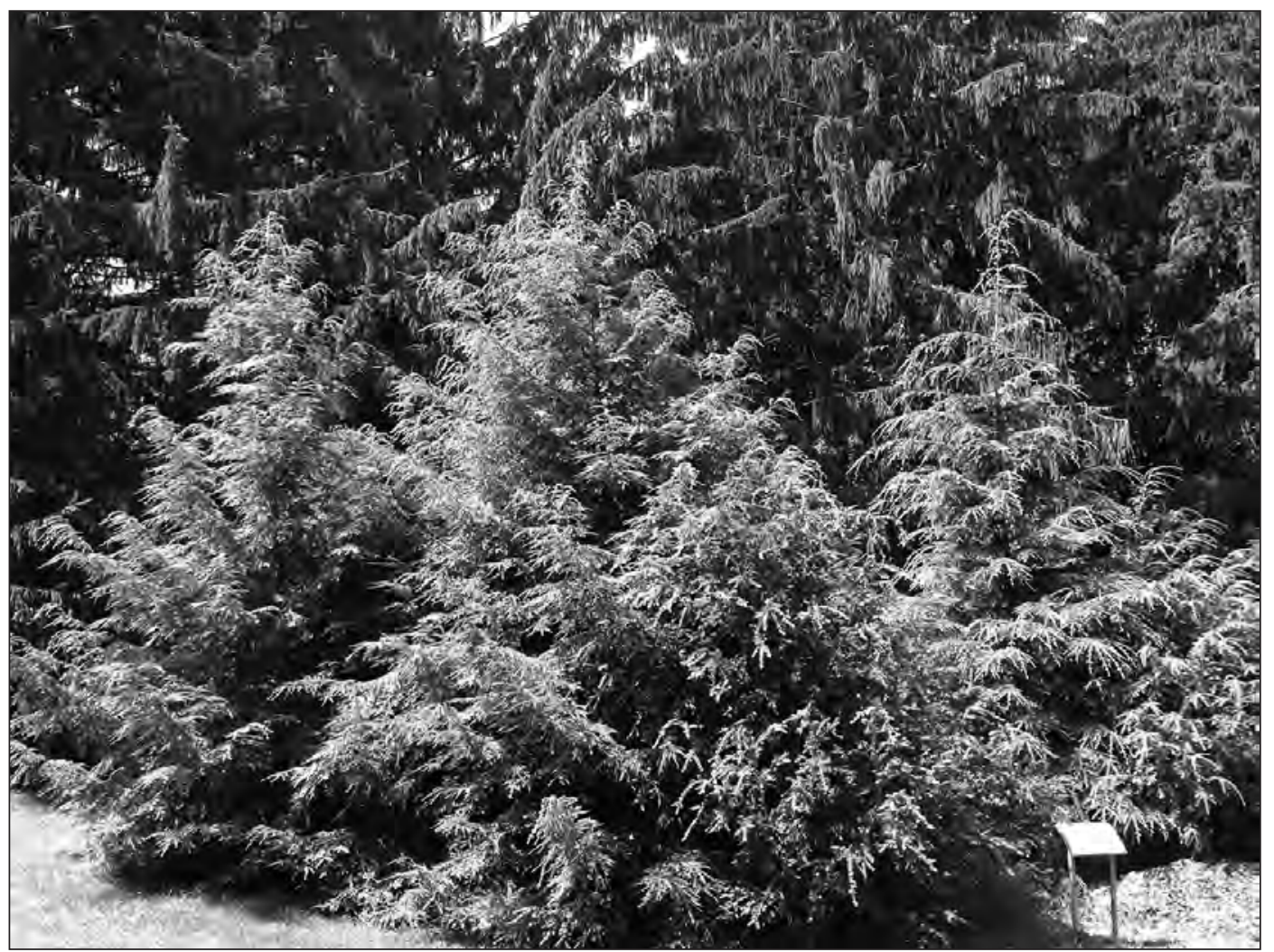

Figure 4. Tsuga spp. Front Gate plot at Lasdon Park \& Arboretum, summer 2012. 
ation will be required to determine if the plants may be successfully lined-out. Exploration of transplantation using softwood cuttings may also prove beneficial and be worthy of formal study.

These results on balance suggest that $T$. chinensis is worthy of serious consideration as a replacement for T. canadensis in landscapes in the northeastern U.S. The growth form of $T$. chinensis shares similarities to that of T. canadensis (Figure 3; Figure 4) as evidenced by the fact that $28 \%$ of study participants comparing the aesthetic properties of $T$. chinensis to $T$. canadensis could not distinguish between the two species (Dampier et al. 2015). Also, the subtle differences between the species (i.e., the larger and deeper green, glossier needles of $T$. chinensis) do not make the plant less attractive as a landscape selection than T. canadensis when comparing consumer purchase preferences (Dampier et al. 2015). The ability of T. chinensis to resist HWA and demonstrate no deleterious effects associated with the presence of EHS is an even more compelling reason to consider T. chinensis as a replacement for T. canadensis. Although further research questions should be addressed concerning this species (e.g., How does it respond to shearing? Is it resistant to deer herbivory? How does it respond to transplantation?), the added benefit of the potential ease of propagating T. chinensis from hardwood cuttings, which are often more difficult to establish than softwood cuttings, bodes well for propagators wishing to establish trade in T. chinensis.

\begin{abstract}
Acknowledgments. The authors wish to thank the following individuals and organizations: Lora Schwartzberg; Jack Alexander (Arnold Arboretum at Harvard University); Chris Joyner and Jeff Anderson (CNS Greenhouses at UMass); John Kinchla (Amherst Nurseries); Stephen DeStefano, Ph.D. (USGS, UMass Amherst); Michael Davidsohn, MLA (UMass Amherst); Brendan Murphy (Watershed Agricultural Council, Yorktown, New York, U.S.); Westchester County Department of Parks, Recreation, and Conservation, including Ted Kozlowski and the entire staff at Lasdon Arboretum.
\end{abstract}

\section{LITERATURE CITED}

Alberty, C.A., H.M. Pellet, and D.H. Taylor. 1984. Characterization of soil compaction at construction sites and woody plant response. Journal of Environmental Horticulture 2(2):48-53.

Anonymous. 2008. Carolina hemlock (Tsuga caroliniana). Virginia Natural Heritage Fact Sheet. Accessed 27 January 2015. $<$ www.dcr.virginia.gov/natural_heritage/documents/fstcaroliniana.pdf>

Anonymous. 2013. Lasdon Park, Arboretum \& Veterans Museum. Accessed 10 December 2013. <http://lasdonpark.org>
Anonymous. 2014. Landscape Plants: Images, Identification, and Information. Volume 3. Oregon State University. Accessed 31 October 2014. <http://oregonstate.edu/dept/ldplants/3plants. htm\#tsuga>

Bentz, S.E., L.G.H. Riedel, M.R. Pooler, and A.M. Townsend. 2002. Hybridization and self-compatibility in controlled pollinations of eastern North American and Asian hemlock (Tsuga) species. Journal of Arboriculture 28:200-205.

Black, R.A., and R.N. Mack. 1976. Tsuga canadensis in Ohio: Synecological and phytogeographical relationships. Vegetatio 32:11-19.

Bryant, J.P., R.K. Swihart, P.B. Reichardt, and L. Newton. 1994. Biogeography of woody plant chemical defense against snowshoe hare browsing: Comparison of Alaska and eastern North America. Oikos 70:385-395.

Coladonato, M. 1993. Tsuga caroliniana. In: Fire Effects Information System. U.S. Department of Agriculture, Forest Service. Rocky Mountain Research Station, Fire Sciences Laboratory. Accessed 30 October 2014. <www.fs.fed.us/database/feis>

Dampier, J.E.E., R.W. Harper, L. Schwartzberg, and R.H. Lemelin. 2015. Comparison of Arborists' and Horticulturists' preferences of Tsuga chinensis to T. canadensis in the urban landscape. Arboriculture \& Urban Forestry 41(1):41-48.

Del Tredici, P. 1985. Propagation of Tsuga canadensis cultivars: Hardwood versus softwood cuttings. Proceedings of the International Plant Propagators' Society 35:565-569.

Del Tredici, P., and A. Kitajima. 2004. Introduction and cultivation of Chinese hemlock (Tsuga chinensis) and its resistance to hemlock woolly adelgid (Adelges tsugae). Journal of Arboriculture 20:282-287.

Dirr, M.A. 2011. Encyclopedia of Trees and Shrubs. Timber Press, Inc., Portland, Oregon, U.S. 951 pp.

Doran, W.L. 1952. The vegetative propagation of hemlock. Journal of Forestry 50:126-129.

Dreistadt, S.H. 2004. Pests of landscape trees and shrubs: An integrated pest management guide. Integrated Pest Management Program, University of California Division of Agriculture and Natural Resources. 210 pp.

Farrar, J.L. 1995. Trees of the Northern United States and Canada. Iowa State University Press, Ames, Iowa, U.S. 502 pp.

Godman, R.M., and K. Lancaster. 1990. Tsuga canadensis. In: R.M. Burns and B.H. Honkala (Eds.). Silvics of North America: Volume 1. Agricultural Handbook 654. USDA, Forest Service, Washington, D.C.

Harper, R.W., and R.S. Cowles. 2013. Susceptibility of Chinese hemlock (Tsuga chinensis) to injury from autumn horticultural oil applications. Arboriculture \& Urban Forestry 39(1):6-10.

Harris, R.W., J.R. Clark, and N.P. Matheny. 2004. Arboriculture: Integrated Management of Landscape Trees, Shrubs, and Vines (fourth edition). Prentice Hall, New Jersey, U.S. 592 pp.

Havill, N.P., and M.E. Montgomery. 2008. The role of arboreta in studying the evolution of host resistance to the hemlock woolly adelgid. Arnoldia 65:2-9.

Hoover, B.K., R.M. Bates, J.C. Sellmer, and G.A. Hoover. 2009. Challenging Chinese hemlock (Tsuga chinensis) with hemlock woolly adelgid (Adelges tsugae) ovisacs. Arboriculture \& Urban Forestry 35(1):1-4.

Jetton, R.M., J. Frampton, and F.P. Hain. 2005. Vegetative propagation of mature eastern and Carolina hemlocks by softwood cuttings. HortScience 40:1469-1473. 
Lapin, B. 1994. The impact of hemlock woolly adelgid on resources in the Lower Connecticut River Valley. Report for the NE Center for Forest Health Research. Hamden, Connecticut, USDA Forest Service. 45 pp.

Larsson, L. 2002. Resistance in trees to insects-An overview of mechanisms and interactions. pp. 1-30. In: M.R. Wagner, K.M. Clancy, F. Lieutier, and T.D. Paine (Eds.). Mechanisms and Deployment of Resistance in Trees to Insects. Kluwer Academic Publishers, Dordrecht, The Netherlands.

Means, J.E. 1990. Tsuga mertensiana. In: R.M. Burns and B.H. Honkala (Eds.). Silvics of North America: Volume 1. Agricultural Handbook 654. USDA, Forest Service, Washington, D.C.

Montgomery, M.E., and A.F. Lagalante. 2008. The role of volatile terpenoids in the relationship of the hemlock woolly adelgid and its host plants. Fourth Symposium on hemlock woolly adelgid in the eastern United States; CT. FHTET 2008-01, 118-123.

Montgomery, M.E., S.E. Bentz, and R.T. Olsen. 2009. Evaluation of hemlock (Tsuga) species and hybrids for resistance to Adelges tsugae (Hemiptera: Adelgidae) using artificial infestation. Journal of Economic Entomology 102:1247-1254.

Oten, K.F., A.C. Cohen, J.B. Strider, and F.P. Hain. 2010. Investigating host resistance using scanning electron microscopy. Proceedings from the Fifth Symposium on Hemlock Woolly Adelgid in the Eastern United States. United States Forest Service (FHTET-2010-07).

Packee, E.C. 1990. Tsuga heterophylla. In: R.M. Burns and B.H. Honkala (Eds.). Silvics of North America: Volume 1. Agricultural Handbook 654. USDA, Forest Service, Washington, D.C.

Quimby, J.W. 1995. Value and importance of hemlock ecosystems in the eastern United States. Proceedings of the first hemlock woolly adelgid review. USDA Forest Service Publication FHTET 96-10.

Weston, P.A., and R.W. Harper. 2009. Potential of Tsuga spp. from western North America and Asia as replacements for eastern hemlock (Tsuga canadensis). Arboriculture \& Urban Forestry 35(1):5-9.

\section{Richard W. Harper (corresponding author) \\ Department of Environmental Conservation \\ 320 Holdsworth Hall \\ University of Massachusetts \\ Amherst, Massachusetts 01003-9285, U.S. \\ rharper@eco.umass.edu}

Paul A. Weston, Ph.D.

School of Agricultural and Wine Sciences and EH Graham

Centre

Charles Sturt University

Wagga Wagga, NSW 2678

Australia

pweston@csu.edu.au
Résumé. Sept espèces de pruche (Tsuga spp.) - quatre de l'Amérique du Nord et trois de l'Asie -ont été évalués dans des parcelles similaires à Katonah, New York, aux États-Unis (zones de rusticité de l'USDA 6b) en tant que substituts potentiels de la pruche du Canada (Tsuga canadensis), qui disparait progressivement des aménagements dans l'est des États-Unis en raison de l'invasion du puceron lanigère de la pruche (Adelges tsugae). Les tendances constatées dans une étude antérieure (Weston et Harper 2009) se sont maintenues, mais elles se sont avérées exagérées après trois années d'observation supplémentaires. Par exemple, la pruche de Chine (T. chinensis) a continué d'afficher le plus grand potentiel de remplacement du $T$. canadensis considérant son faible taux de mortalité, sa santé globale exceptionnelle et sa tolérance élevée à $A$. tsugae. Les premiers indicateurs suggèrent que le $T$. chinensis peut également être aisément propagé à partir de boutures ligneuses dans des conditions de serre appropriées. Ces caractéristiques suggèrent que le T. chinensis peut en effet devenir un substitut fiable pour le T. canadensis et un apport précieux dans les aménagements paysagers de l'est des États-Unis.

Zusammenfassung. Sieben Arten von Tsuga-Species - vier aus Nordamerika und drei aus Asien - wurden in nachgebildeten Flächen in Katonah New York, U.S. (USDA Plant Hardiness Zone 6b) als möglicher Ersatz für die Östliche Hemlocktanne (Tsuga canadensis), welche graduell aus den Landschaften der Östlichen Vereinigten Staaten von der invasiven Hemlocktannenstammlaus (Adelges tsugae). vertrieben wird. Die in einer früheren Studie (Weston and Harper 2009) berichteten Trends hielten an, aber sie waren nach weiteren drei Jahren der Beobachtung übertrieben. Zum Beispiel zeigte die Chinesische Hemlocktanne das größte Potential als Ersatz für T. canadensis, weil die Absterberate sehr gering war, die Pflanzengesundheit außergewöhnlich und die Toleranz gegenüber der Hemlocktannenstammlaus hartnäckig waren. Frühe Indikatoren sagen, dass die Chin. Hemlocktanne auch praktikabel aus Hartholzstecklingen unter angemessenen Glashausbedingungen gezogen werden kann. Diese Charakteristika verdeutlichen, dass die Chin. Hemlocktanne tatsächlich die gesunde Alternative werden kann und eine Bereicherung der Landschaften der östliche Vereinigten Staaten sein könnte.

Resumen. Siete especies de abeto (Tsuga spp.) - cuatro de América del Norte y tres de Asia - fueron evaluadas en parcelas replicadas en Katonah, Nueva York, Estados Unidos (USDA Zona $6 \mathrm{~b}$ de resistencia) como sustitutos potenciales para el abeto oriental (Tsuga canadensis), el cual poco a poco está siendo extinguido de los paisajes en el este de Estados Unidos por la invasión del pulgón de la tsuga (Adelges tsugae). Las tendencias reportadas en un estudio anterior (Weston y Harper 2009) continuaron pero fueron exageradas después de tres años adicionales de observación. Por ejemplo, el abeto chino (T. chinensis) continuó mostrando el mayor potencial como un reemplazo para T. canadensis ya que la mortalidad es muy baja, la salud general de la planta fue excepcional y la tolerancia a $A$. tsugae fue robusta. Los primeros indicadores sugieren que $T$. chinensis también se puede propagar fácilmente a partir de esquejes de madera dura bajo condiciones de invernadero apropiadas. Estas características sugieren que T. chinensis de hecho puede convertirse en un reemplazo viable para T. canadensis y una adición valiosa a los paisajes en el este de U.S. 